\title{
Interactive Module Design Using The Course Lab Application Based on a Scientific Approach to Materials Business, Energy and Momentum
}

Akira Daichi', Arata $\mathrm{Gin}^{2}$, Arta Eiji ${ }^{3}$

Victoria Univesity

Australia

e-mail: akiradaichi19@yahoo.com , arata.gin@yahoo.com , artaeiij@yahoo.com

To cite this document:

Akira Daichi, Arata Gin, \& Arta Eiji. (2020). Interactive Module Design Using The Course Lab Application Based on a Scientific Approach to Materials Business, Energy and Momentum. IAIC Transactions on Sustainable Digital Innovation (ITSDI), 2(1), 75-84.

DOI : https://doi.org/10.34306/itsdi.v2i1.355

\begin{abstract}
A well-prepared abstract enables the reader to identify the basic content of a document quickly and accurately, to determine its relevance to their interests, and thus to decide whether to read the document in its entirety. The Abstract should be informative and completely self-explanatory, provide a clear statement of the problem, the proposed approach or solution, and point out major findings and conclusions. The Abstract should be 100 to 150 words in length, the font style is Arial in Italic mode and the font size is 10. The abstract should be written in the past tense. Standard nomenclature should be used and abbreviations should be avoided. No literature should be cited. The keyword list provides the opportunity to add keywords, used by the indexing and abstracting services, in addition to those already present in the title. Judicious use of keywords may increase the ease with which interested parties can locate our article.
\end{abstract}

Keywords: Materials Business, Energy, Design 


\section{Introduction}

Education is one of the most important keys in the moral order, character and potential of a nation. The development of education must adapt to the updates that occur and keep up with the times. In this era of globalization, almost all technological products use physics. Physics is very important and plays a role in the development of science and technology. Seeing the importance of physics, there must be a change for the better so that physics learning is not boring.

Physics is a science that supports technology and information. Physics is a branch of science that can explain natural phenomena and phenomena empirically, systematically, and logically. Physics and science and technology are a very closely related unit, because science and technology will not develop without physics.

Physics is a very important subject which students begin to learn since the basic education level, secondary education, both SMP / MTs which are incorporated into science and SMA / MA subjects, which have become separate subjects, namely physics. Physics can explain various natural events that can be observed and seen directly in everyday life. Physics should be the most interesting subject for students because after studying physics, students can see firsthand the phenomena that are studied in everyday life.

Seeing the important role of physics in life, various efforts have been made by the government to improve the quality of educational outcomes. Among them are making improvements and completing school infrastructure, improving the welfare of educators with certification, and making changes to the curriculum to make it better than the previous curriculum.

Researchers in the field of education have also carried out various studies that have followed current technological developments by creating creative and attractive application programs with the help of computers. The development of interactive media aims to increase students' interest in learning which has an impact on learning outcomes. Among the researchers, Festiyed developed a computer-assisted interactive program to increase students' attention to learning. Festiyed and Djusmaini Djamas developed interactive multimedia physics teaching materials based on a scientific approach to improve students' critical thinking skills. Research conducted by Zul Azhari, Djusmaini Djamas, Yulkifli, and Festiyed showed that students' interest in using multimedia and games was high around $86.2 \%$ and $85.6 \%$.

Furthermore, in research conducted by Festiyed, D Djamas, and Ramli, it was found that interactive multimedia teaching materials proved effective in improving students' critical thinking skills. From the results of research from lecturers and education experts, it can be seen that using interactive multimedia in learning can improve critical thinking skills and increase student interest in learning. The reality in the field is based on observations made at SMAN 1 Batusangkar, it is seen that in learning, students receive and copy more what the teacher says because the method used in learning is the lecture method that focuses on learning, to the teacher (teacher centered). During the learning process it has not been seen that all components of the scientific approach are carried out by students which are caused by lack of teaching materials or modules.

Learning devices used such as textbooks or printed modules do not attract the attention of students because educators are not familiar with using computers or technology in learning. So that with the lack of teaching materials or modules used, it cannot meet the diversity of learning methods of students. Interactive multimedia is made in such a way that students can interact directly with the media. The making of teaching materials in the form of interactive multimedia modules is made using the Course Lab 2.4 software which will be developed to produce interactive learning. Course Lab is a software for compiling teaching 
materials, in the form of modules that are easy to download for free. The advantage of this application is that it can be used for interactive evaluation questions, which can be published on a CD-ROOM or flash disk.

Learning devices used such as textbooks or modules in the form of print do not attract the attention of students because of educators not used to using computers or technology in learning. So that the lack of teaching materials or modules used cannot meet the diversity of learning methods of students.

Teaching materials are part of the learning resources. Teaching materials are all forms of materials used to assist teachers / instructors in carrying out teaching and learning activities. Material, which is meant in the form of written material or unwritten material. Teaching materials or instructional materials generally consist of the knowledge, skills, and attitudes that students must learn, in order to achieve predetermined competency standards [6].

So, teaching materials are a guideline or one of the learning resources for teachers and students in directing all learning process activities that aim to simplify the learning process that can help teachers deliver subject matter and help students understand the material presented by the teacher so that learning objectives can be achieved.

Modules are tools, or learning tools that contain material, methods, limitations, and ways of evaluating which are designed systematically and attractively to achieve its complexity. A module is a set of teaching materials that are presented systematically so that users can teach with or without a facilitator / teacher. Thus, a module must be able to present a teaching material as a substitute for the teacher's function. The module is basically a teaching material that is arranged systematically in language that is easily understood by students according to their level of knowledge and age, so that they can learn on their own (independently) with minimal assistance or guidance from educators. If the teacher has a function, explaining something, then the module must be able to explain something in language that is easily accepted by students according to their level of knowledge and age.

In order to produce a good module that can be used in the learning process, in its manufacture, the objectives of the module must be considered. One of these objectives is so that students can learn independently. Creating a module has the following objectives:

1) So that students can learn independently or with the guidance of educators (which is minimal)

2) So that the role of educators is not too dominant and authoritarian in learning activities

3) Train the honesty of students

4) Accommodate various levels and learning speeds of learners

5) So that students are able to measure their own level of mastery, the material that has been studied

The module consists of four main parts, namely the introduction, learning, evaluation, and closing parts. Instructions for using the module can be found in the introduction. The learning section of a module contains several learning activities. Each activity, learning includes the purpose of learning activities, material descriptions, summaries, assignments, formative tests, and formative test answer keys. Evaluation questions along with the evaluation answer key are in the evaluation section. In the closing section, there is a bibliography. In the development guide, teaching materials states that at least the module contains:

1) Study instructions (student / teacher instructions)

2) Competence to be achieved

3) Content or content of the material

4) Supporting information

5) Exercises 
6) Work instructions, can be in the form of worksheets

7) Evaluation

8) Feedback on evaluation results

Interactive if there must be two parties involved in the learning process. There must be feedback between the user and the media he uses. Media, or learning materials, can respond to attitudes or steps taken by users. Responses or responses must be able to understand the steps taken, by the user, that the response is educational. Multimedia in the use of several different media in conveying information in the form of text, audio, graphics, animation, and video. Based on this understanding, multimedia can be defined as a means of channeling information presented through text, images, graphics, animation, and video.

Multimedia used in learning has several characteristics, namely,

(a) has more than one convergent media, such as containing audio and visuals,

(b) is interactive, there is a reciprocal relationship (feedback) between the user and the media, and

(c) is independent, with multimedia allows users to use the media without the guidance of others.

The multimedia used is controlled directly by the user and there is feedback received by the user. The use of interactive multimedia can also be used by teachers in carrying out various activities in the learning process. So, interactive multimedia is a media equipped with a control device that can be operated by multimedia users. So that users can choose and organize multimedia according to what they want for next process. Interactive multimedia is a process of feedback between users and the media or applications they use. When the user performs an action, the application responds to the action of the user.

Characteristics of learning designs that need to be considered are:

a. Content Representation

In order for learning to be interactive teaching materials, what is made needs to be selected first. The selected material must be representative, consisting of elements of animation, video, audio, simulation

b. Uses, attractive colors and high resolution graphics

In use, the colors in the template are made with digital engineering technology with high resolution but, support for any computer speech system. An attractive appearance by reproducing images and objects according to the demands of the material, will increase students' interest in teaching materials.

c. Various types of learning

Type of learning, collaborative between types of tutorials, simulations, games, and exercises.

d. Learning responses and strengthening interactive learning that can respond to stimuli provided by students when operating the program, in the form of branching

e. Developing the principle of self-evaluation Interactive learning provides facilities where students can practice their ability to master the material with the questions that have been provided. Students can also see, the score of learning outcomes obtained after practice

So from the description above, it can be concluded that the characteristics of the learning design that meet the representation of the content, with elements of animation, video, are made to be more interactive and use colors, which are attractive, and use various types of learning so that they can respond to stimuli. given by students. In this study, researchers made teaching materials in the form of interactive multimedia modules so that an interactive learning process would occur. So that researchers make modules using the course lab application, based on a scientific approach 


\section{Research Method}

This research is a mix-method research which is a combination of approaches Qualitative and quantitative. This study aims to determine the validity of an interactive module product according to the steps for making teaching materials in the form of modules according to the Ministry of National Education (2008) such as:

1) main display / cover,

2) display of learning instructions,

3) display of competencies to be achieved,

4) content of the material,

5) supporting information,

6) exercises,

7) worksheets of students, and

8) evaluation.

a product that is designed can be done by presenting several experienced experts to assess the product so that its strengths and weaknesses can be identified. Validation of the module was carried out by four validators, namely three physics lecturers of Faculty of Mathematics and Natural Sciences UNP and one physics teacher at SMAN 1 Batusangkar. In this study, the research procedure began with a qualitative approach, namely finding potentials and problems in the field, then continued with the steps for compiling modules based on the Ministry of National Education (2008), while the quantitative approach was the result of the validity test. According to the Ministry of National Education (2008) in writing teaching materials, especially modules, there are several stages that must be passed, namely:

\subsection{Identifying Potentials and Problems}

Research starts from a potential or problem. Potential is anything that if utilized will have added value, while the problem is the deviation between what is expected and what is happening. Based on observations that have been made at SMAN 1 Batusangkar the potential in these schools generally already has adequate facilities and infrastructure in the physics learning process and procurement complete computer. On the other hand, the problem faced is the absence of teaching materials

in accordance with the 2013 curriculum which uses a scientific approach and has not yet developed teaching materials in the form of interactive modules or that utilize computer technology. In addition, there are still problems that arise in learning physics, including modules made by the teacher that have not been able to make students interested and active in learning. The benefit of this interactive module is that students can study anywhere without having to bring books. Because most of the students bring laptops to school and the number of computers in the school is quite facilitating.

\subsection{Steps for Creating an Interactive Module}

After making observations and getting potentials and problems, the next step is to compile an interactive module according to the steps, writing modules at the Ministry of National Education. According to the Ministry of National Education, in writing teaching materials, especially modules, there are several stages that must be passed, namely:

\section{a. Analysis of $\mathrm{KI}$ and $\mathrm{KD}$}

The analysis is intended to determine which materials require teaching materials. In determining the material analyzed by looking at the core of the material to be taught, then the competencies that must be owned by students and the critical learning outcomes that students must have (criticall learning outcomes) like what.

\section{b. Specifies Module Titles}

The module title is determined on the basis of KD-KD or the learning material contained in the syllabus. One competency can be used as a module title if the competency is not too large, while the amount of competency can be detected, among others, by breaking it 
down into the subject matter to get a maximum of $4 \mathrm{MP}$, then that competency can be used as a single title, module. However, if it is broken down into more than $4 \mathrm{MP}$, it is necessary to reconsider whether it needs to be broken down, for example int 2 module titles.

\section{c. Create a Storyboard}

The module which is made is an interactive module, so before starting the creation, you have to make a storyboard first. A storyboard is a sketch of an image design that is arranged sequentially which serves to convey the initial idea in making a product before the actual product is made and explains the product flow in general.

\section{d. Writing Module}

Writing modules, in accordance with the module structure developed from the Ministry of National Education, the structure of the Interactive Module using the Course Lab Application based on the Scientific Approach on Business, Energy, and Momentum materials, including:

a) Cover, contains the front page of an interactive module based on a scientific approach using the course lab application for business and energy materials as well as momentum and impulses.

b) Teaching materials, containing the structure of interactive modules based on a scientific approach using a lab course application for business and energy materials as well as momentum and impulses in physics learning for Class X Senior High School.

The interactive module sections consist of:

1) Learning instructions, contains learning instructions that must be, understood and followed by students in the learning process.

2) Competence and indicators, containing core competencies, basic competencies, and indicators.

3) Learning materials, containing descriptions, materials and examples of questions about related materials.

4) Supporting information, contains a variety of additional information that can complement the interactive module so that students find it easier to master, the material to be studied.

5) LKPD, contains worksheets that must be done and completed by students.

6) Evaluation, contains interactive questions so that it makes students more interested and motivated to increase understanding of the material being studied.

\subsection{Design Validation}

Validation is an assessment of the feasibility of a product design. A tool is said to be valid if the tool measures what it should be measured. Validation, the design is needed to find out whether the product being designed is valid or not. The validity of product design is carried out by lecturers as experts. There are 3 lecturer validators. The categories assessed by the lecturer were material substance, clarity and physical form of the module, learning design, and the form of assistance provided from the questions.

\subsection{Design Revision}

After the product design is validated, the description of the validation results and the weaknesses in the product is known. Researchers make improvements from the design based on the weaknesses put forward by experts. The validity of the module was assessed by a lecturer at the Department of Physics, Padang State University. The statistical test carried out in this validity is descriptive analysis which is depicted through graphics. Weighting is done, based on a Likert scale. The Likert scale is used to measure a person's attitudes, opinions, and perceptions about social phenomena. Answer, each instrument that uses the Likert scale has a detailed score as follows:
a. Score 5 for the answer, totally agree
b. Score 4 for agreed answers
c. Score 3 for answers, hesitate
d. Score 2 for the answer disagree 
e. Score 1 for the answer, strongly disagree.

\section{Research Results}

There are two main results in this research, namely the results of the preparation of the Interactive Module using the Course Lab Application based on the Scientific Approach on the material of Business, Energy, and Momentum from the aspect of validity.

\subsection{Module Validity Test Results}

The validation of this module was carried out by three lecturers of Physics at the Faculty of Mathematics and Natural Sciences UNP and one physics teacher at SMAN 1 Batusangkar. The results of validation carried out by experts are used to determine the feasibility of an interactive module using a lab course based on a scientific approach for learning physics in SMA / MA.

After conducting the validation test on 4 validators, qualitatively, from validator 1 the researcher conducted a validation test with suggestions, namely making improvements such as separating the application assessment section and the scientific approach to the instrument, creating a validation guide to make it easier for the validator to assess the interactive module that had been made, add a material section still incomplete, such as the derivative of the formula in some parts of the equation and various energies, and making the answer key for each existing evaluation question. In the assessment section, identification of the completeness of the module, all components are complete and can be said to be a module. After making improvements according to suggestions from the number of indicators then the range of values from the validity criteria is obtained in the following table.

Table 2. Product Validity Criteria based on Instrument

\begin{tabular}{|c|c|c|}
\hline No. & Percentage & Criteria \\
\hline 1. & $21-36$ & Invalid \\
\hline 2. & $37-52$ & Less Valid \\
\hline 3. & $53-68$ & Quite Valid \\
\hline 4. & $69-84$ & Valid \\
\hline 5. & $85-100$ & Very Valid \\
\hline
\end{tabular}

Quantitatively, the analysis results from validation what has been done is presented in tabular form following.

Table 3. Results of the Interactive Module Validity Test

\begin{tabular}{|l|l|l|}
\hline \multicolumn{1}{|c|}{ Validator } & \multicolumn{1}{|c|}{ Score } & \multicolumn{1}{|c|}{ validity criteria } \\
\hline 1. & 78 & Valid \\
\hline 2. & 100 & Very Valid \\
\hline 3. & 90 & Very Valid \\
\hline
\end{tabular}




\begin{tabular}{|l|l|l|}
\hline 4. & 96 & Very Valid \\
\hline
\end{tabular}

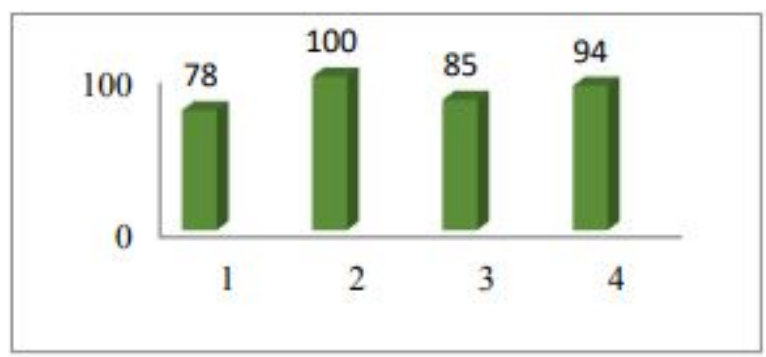

Based on the assessment instrument on interactive modules, using a lab-based course the scientific approach has components in the form of: validity, content (content feasibility and eligibility language), construction validity (component presentation, graphic, scientific approach, and utilization of software). Content validity relates to product arrangement, according to the design which have been specified. Interactive module design This starts from the identification of completeness, which module consists of guidance, learning, competence to be achieved, the content of the material, supporting information, exercises, worksheets, evaluation, and feedback or feedback on modules. Then the assessment is on validity of the content that contains,: the material presented in modules are in accordance with the demands of $\mathrm{KD}$ and formulated indicators, objectives, learning according to the indicators, and the appropriate material with the aim of learning.

There is a linguistic component indicator: The way of writing the terms in writing, use of signs, read in writing, writing sentences in the module is clear and easy to understand, language, used in the module is effective, the writing is in accordance withEBI (Indonesian Spelling), and clarity information in the module. Construction validity refers to means construct, in this research is how to develop a product. On The validity of this construction has 3 components, namely presentation component, graphic component, and linguistic component. On, the serving component there are hint indicators, learning on modules, students' understanding of the material in modules, supporting information, suitability of the experiment with material, and questions, evaluation on the module.

There is a graphic component indicators: font usage, type and size in appropriate and attractive modules, title and sub layout the title in the module is appropriate and good, placement of illustrations, pictures, and photos inside the module has a suitable, and attractive, display design the overall module is interesting, and a blend color on, cover and each module slide already proportional. Assessment component part of the approach There are scientific and Course Lab Application components Indicators: Integrity, material with an approach scientific, components of the scientific approach already complete, scientific steps already, illustrated with clear, scientific knowledge / concepts in the module correct, audio or video, which is in the module relating to material, learning, having the ability to accommodate user responses (interactive), the module has a display design simple and attractive, and, every slide is included multimedia whether text, animation, sound, or video.

The following is a table of results of content validity and construct validity. It can be concluded that the content validity of the module is in accordance with the desired content, because get, the validity of the criteria is very valid. For the construct feasibility of all components get criteria, very valid. For validity construct it can be concluded that the module already have the arrangement, which is very good, because it has construct validity, which is very valid. Quantitatively the results of the analysis, content validity and construct validity, can be seen in the table following.

Table 4. Results of Content Validity and Construct Validity 


\begin{tabular}{|c|c|c|c|c|c|c|c|}
\hline \multirow[b]{2}{*}{ No. } & \multirow{2}{*}{$\begin{array}{l}\text { Aspects of The } \\
\text { Assessment }\end{array}$} & \multicolumn{4}{|c|}{ Validator } & \multirow[b]{2}{*}{ Amount } & \multirow[b]{2}{*}{$\begin{array}{l}\text { Validity } \\
\text { value }\end{array}$} \\
\hline & & 1 & 2 & 3 & 4 & & \\
\hline 1. & Content Eligibility & 20 & 15 & 18 & 18 & 71 & 88,8 \\
\hline 2. & Serving Feasibility & 28 & 35 & 29 & 33 & 125 & 89,3 \\
\hline 3. & linguistic eligibility & 24 & 30 & 25 & 28 & 107 & 89,2 \\
\hline 4. & $\begin{array}{l}\text { The Graphic of The } \\
\text { Module }\end{array}$ & 19 & 25 & 21 & 23 & 88 & 88 \\
\hline 5. & Scientific Approach & 16 & 20 & 17 & 19 & 72 & 90 \\
\hline 6. & $\begin{array}{l}\text { Utilization of the } \\
\text { Course Lab } \\
\text { Software }\end{array}$ & 15 & 20 & 18 & 20 & 73 & 91,2 \\
\hline \multicolumn{7}{|c|}{ Jumlah } & 536,5 \\
\hline
\end{tabular}

During the validation process, the validators give suggestions, which are written inside validation instrument, the suggestions become basic considerations for revising the module, interactive. The following revisions have been made by researchers based on the suggestions of the four validators. In the validation instrument there are suggestions from validator, namely before, in the revision of the assessment for scientific approach and software utilization put in, serving eligibility, after revised made in the new title points viz scientific approach and software utilization.

\section{Discussion}

This research aims to produce interactive module using the application Course Lab based on a valid scientific approach. validity assessment, conducted by four people validator consisting of three physics lecturers FMIPA UNP and one subject teacher Physics at SMAN 1 Batusangkar. After doing the validation test on 4 the validator, qualitatively then from the results validation and suggestions,, the validator on the sheet validation, it is known, that it needs to be revised the product produced. The revision carried out mainly regarding validation instruments, completeness of material, equations, videos, writings, and picture. After being revised the resulting product more perfect than before. From the results of the analysis on the expert validation sheet the value is obtained the validity of the mean for the components assessed by lecturers as experts of 89.4. This matter indicates that the resulting product are in the very valid category.

\section{Conclusion}

Based on the research that has been conducted, then obtained two research results. First, this research produces a product in the form of an interactive module using the Course Lab application based on a scientific approach to business materials, energy, and momentum. And the results of the second study is the result of the validity test, which is carried out by three a UNP Physics lecturer and a high school physics teacher 1 Batusangkar with validity results 89.4 with validity criteria are very valid. So it can be 
concluded that the interactive module uses the application Approach-based Course Lab, scientific on This effort, energy, and momentum is well worth it used in learning.

\section{References}

[1] Festiyed. 2008. Peningkatan Perhatian Belajar Siswa Berbantuan Program Komputer Interaktif. (Disertasi). Pascasarjana UNP. Padang

[2] Festiyed, Djusmaini Djamas. 2015. Pengembangan Bahan Ajar Fisika Multimedia Interaktif Berbasis Scientific Approach Untuk Meningkatkan Keterampilan Berpikir Kritis Peserta didik SMA. Hibah,Penelitian. Universitas Negeri Padang. Padang

[3] Zul Azhari, Djusmaini Djamas, Yulkifli, dan Festiyed. 2018. Preliminary study of the use of games interactive multimedia module to increase critical thinking of students in senior high school. Padang : Journal of Physics UNP.

[4] Festiyed, D Djamas, dan Ramli. 2018. Learning model based on discovery learning equipped with interactive multimedia teaching materials assisted by games to improve critical thinking skills of high school students. Padang : Journal of Physics UNP

[5] Depdiknas. 2008. Pengembangan Materi Pembelajaran. Jakarta: Direktorat, Jenderal Manajemen Pendidikan Dasar dan Menengah, Direktorat Pendidikan Sekolah Menengah Atas.

[6] Abidin, Yunus. 2014. Desain Sistem Pembelajaran dalam Konteks Kurikulum 2013. Bandung: PT. Refika Aditama.

[7] Andi, Prastowo. 2011. Panduan Kreatif Membuat Bahan Ajar Inovatif. Yogyakarta: DIVA Press.

[8] Waryanto, Nurhadi. 2008. Multimedia Interaktif Dalam Pembelajaran. Yogyakarta: FMIPA UNY

[9] Daryanto. 2014. Pendekatan Pembelajaran Saintifik Kurikulum 2013. Yogyakarta: Grava Media.

[10] Sugiyono. 2012. Metode Penelitian, Kuantitatif, Kualitatif dan R\&D . Bandung : Alfabeta.

[11] Riduwan. 2009. Pengantar, Statistika untuk Pendidikan, Sosial, Ekonomi Komunikasi, dan Bisnis. Bandung : Alfabeta

[12] Arikunto, Suharsimi. 2008. Dasar-dasar Evaluasi Pendidikan. Jakarta: Bumi Aksara. 